Volume 6, Number 1, 2020

\title{
Mathematical Modelling of Heat Transfer System of Convective Heating Surfaces of TPP-210A Steam Boiler
}

\author{
Igor Galyanchuk ${ }^{*}$, Taras Kravets \\ Lviv Polytechnic National University, 12 S. Bandera St., Lviv, 79013, Ukraine
}

Received: February 13, 2020. Revised: March 12, 2020. Accepted: March 19, 2020.

(c) 2020 The Authors. Published by Lviv Polytechnic National University.

\begin{abstract}
A mathematical model and the respective structural scheme of the convective heating surfaces of the TPP-210A steam boiler were developed as a system of interconnected heat exchangers. The interconnected convective heating surfaces are regarded as the convective heat transfer system of the boiler. The obtained results of modelling of the convective heat transfer system enable mode calculations of the dependence of the temperature and thermal mode of the heating surfaces on the variation of the heat carriers input temperature, relative changes of the heat carrier flow and heating surface area. This mathematical model is practicable for revealing possible improvements of the convective heat transfer system and for assessing the effects of the changes made to the heat transfer system basing only on the known values of the input and output temperatures of the heat carriers in the initial mode.
\end{abstract}

Keywords: mathematical model; heat transfer system; convective heating surfaces; scheme; parameters; temperature; heat carrier; heat exchanger.

\section{Introduction}

The simplest element of the heat transfer system is a heat exchanger. The models of the counter-flow and directflow heat exchangers were first developed as early as the last century and were presented by equations not using the temperature drop, which significantly restricted the scope of their practical application [1], [2].

In the process of operation, study and maintenance of heat and power equipment at thermal power stations, it is necessary to assess the effect of different mode changes on the conditions and indicators of operation of both certain units and their assemblies.

For the steam boiler, the following mode factors are to be considered:

- heat carrier flow (air, water, steam, flue gas) at the inlet of the steam boiler or of its particular heating surfaces;

- temperature of the heat carriers at the inlet of the steam boiler and its units;

- heating surfaces condition (how soiled they are);

- bypassing, recirculation and cross-flow of the heat carriers;

- additional inletting and discharging of the heat carriers.

The above specified mode factors determine the changes of the heat carrier temperature at the inlet of the boiler and at the outlet from its unit assemblies. This results in a change of the efficiency and reliability of the boiler [3]-[5].

Sometimes inverse mode problems need to be solved, when necessary input mode changes are determined in order to achieve the needed value of the output temperature of the heat carrier. There are diagnostic mode problems,

\footnotetext{
${ }^{*}$ Corresponding author. Email address: i_galyanchuk@yahoo.com
}

This paper should be cited as: I. Galyanchuk, T. Kravets. Mathematical modelling of heat transfer system of convective heating surfaces of TPP-210A steam boiler. Energy Engineering and Control Systems, 2020, Vol. 6, No. 1, pp. 16 - 22. https://doi.org/10.23939/jeecs2020.01.016 
when probable reasons for the deviation of the input temperatures of the heat carriers from the design value or the nominal one are determined.

Conventionally, the above-mentioned correlations are established empirically. However, as the capacity, parameters and dimensions of the equipment grow, the experiments become more complicated, time-consuming and expensive. In many cases, not all the correlations can be found experimentally. This also directly applies to the TPP210A steam boilers of the 300 MW power generating unit of the Trypillia Thermal Power Station.

The conventional methods of design and checking of the calculations for solving mode problems turned out to be low-efficient or even inapplicable. Their application requires large volumes of initial information, which is hardly available or totally unavailable both at the initial stages of new equipment design and in its operation conditions, when the equipment is worn-out or soiled, or the conditions of its operation differ from those specified in the design documentation.

These difficulties drive the development of special models and methods of calculation, which would make it possible to establish the mode dependencies promptly and efficiently based on a limited scope of the most easily available initial data. There has been already gained a certain experience in the developing of such methods and their application [6]-[9].

However, the results of such guides' development have not been sufficiently generalized or organized; the corresponding changes and improvements are needed, and they should be made more user-friendly.

This research focuses on the development of the mathematical model and corresponding structural scheme of the convective heating surfaces of the TPP-210A steam boiler for their further use in order to ensure mode calculations and study of the heating surfaces of both individual heat exchanging units and their assemblies [6]. The dependencies of the power transferred between the heat carriers and the output temperature of the heat carriers on the input temperature variation, relative change of the heating surface area and heat carriers flow are, first of all, established [7].

The main initial data includes the values of the input and output temperature of the heat carriers in an arbitrary known mode of operation of the heating surfaces. The absolute values of the heating surfaces' area and heat carrier flow can be unknown.

The changed values of the output parameters are determined for the conditions when the transient process has ended. The transient dynamics and the effect of mode changes on the efficiency of the steam boiler, strength and corrosion resistance of the surfaces should be the subject of special studies.

\section{The structural scheme and mathematical model of the convective heat transfer system of the TPP-210A steam boiler}

\subsection{The structural scheme of the convective heat transfer system of the TPP-210A steam boiler}

The initial data for modelling and performing mode calculations was provided by the Trypillia Thermal Power Station in the form of flow pattern maps for the heat carriers in the convective heating surfaces of the TPP-210A steam boiler, with the heat carrier temperatures specified. The combination of the convective heating surfaces of the steam boiler, including three subsystems, air heater (A), water economizer (B) and intermediate superheater (C), will be considered further on as the convective heat transfer system (HTS) of the steam boiler.

Using the system of symbols for the elements and shape of the charts images adopted in this study, the heat transfer system is shown in Fig.1,a, and with numbers of the elements and heat carrier temperature values in Fig.1,b.

\subsection{The mathematical model of the convective heat transfer system of the TPP-210A steam boiler}

The specific feature of the convective heat transfer system is that one and the same heating heat carrier (flue gasses) flows through each subsystem consecutively. The heated heat carriers in all the subsystems are different (air, water, steam). All the subsystems consist of two flows of heat carriers, each one having two inlets and two outlets for the heat carrier.

If the mode problem aims to determine the correlations or cross impact of the subsystems without analyzing the internal changes in the subsystems, each subsystem can be operationally replaced by a similar heat exchanger. In such heat exchanger, the values of the input and output temperatures of the heat carriers must be equal to the values at the corresponding inlets and outlets to the subsystems. 


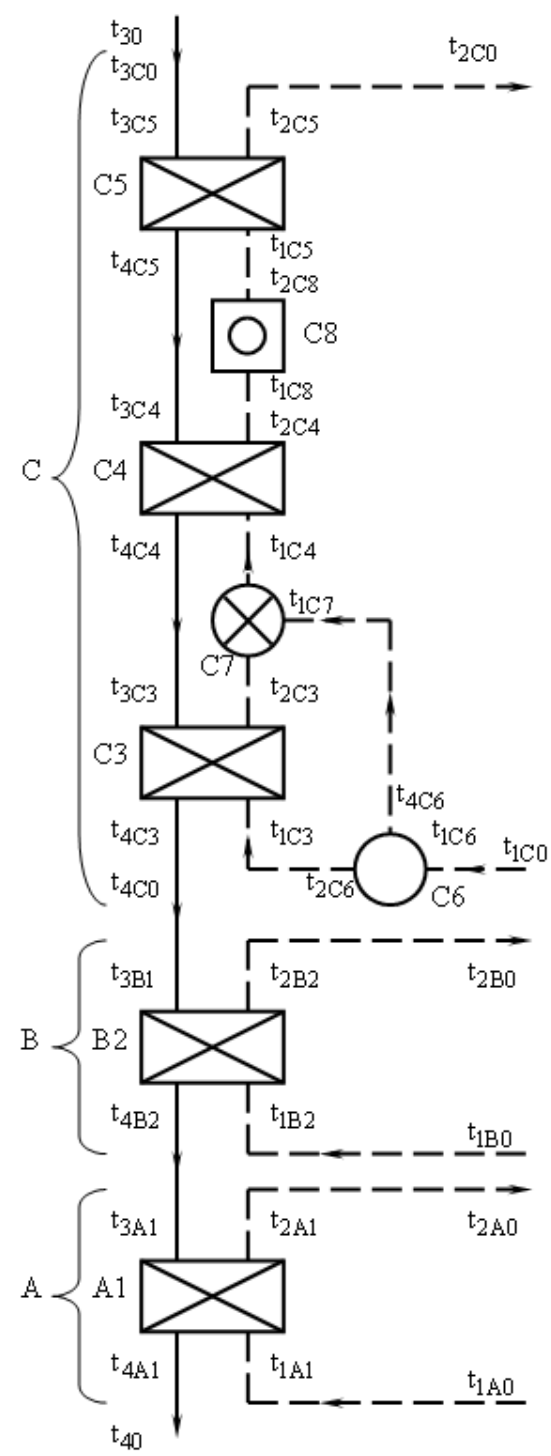

$a$

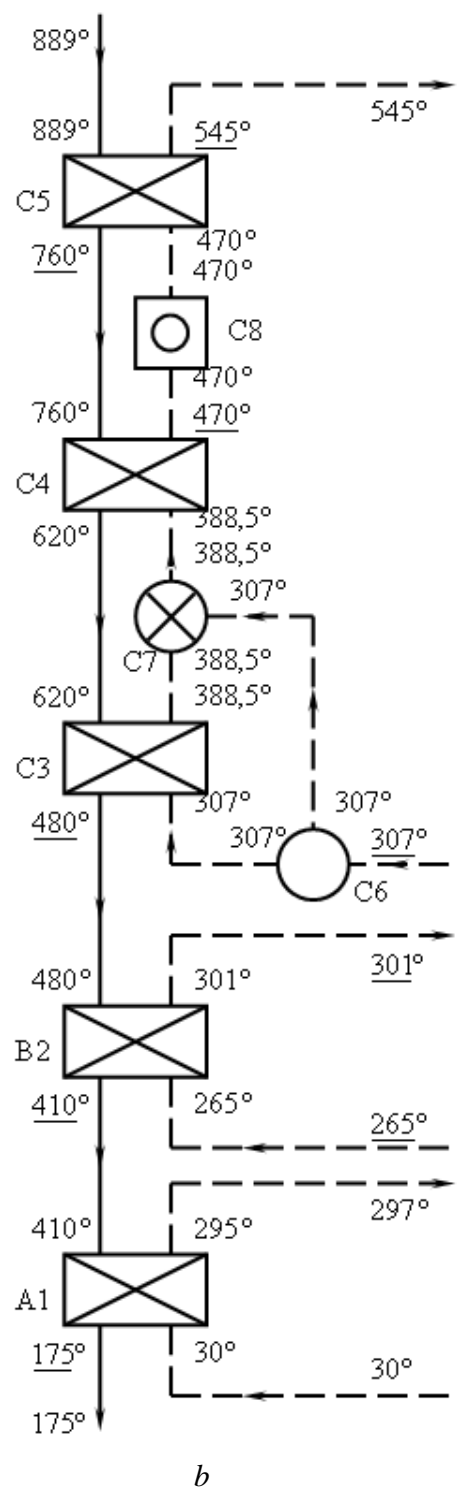

$b$

Fig.1. The structural scheme of the convective heating surfaces of the steam boiler TPP-210A $\mathrm{A}$ - air heater; $\mathrm{B}$ - water economiser; $\mathrm{C}$ - intermediate superheater.

As a result, the heat transfer system of the steam boiler assumes the structure presented in Fig.2. This is a sequence of the flows of the heated heat carriers along the flow of the heating heat carrier. The subsystems A, B and $\mathrm{C}$ are the elements of this sequence.

This system consists of four flows with four flow inlets and four flow outlets, respectively, and is viewed as autonomous, as all the flows are independent.

In fact, variation of the air, water and steam temperatures partially influences the temperature of gases in the boiler furnace, which, in its turn, influences the temperature of gases at the inlet to the system $\left(t_{3 C}\right)$. This effect, however, is of minor significance and can be disregarded in most practical problems.

The information on the status of the subsystem and changes in it, being presented by the output temperature values or their changes, is transmitted to other subsystems.

The basic structural scheme (Fig.2) shows that changes in the air heater affect only its output temperatures. They have no effect on the water economizer or superheater. Changes in the water economizer influence both its output temperatures and the temperatures in the air heater, and do not affect the superheater. Changes in the superheater have an effect on all the subsystems. 

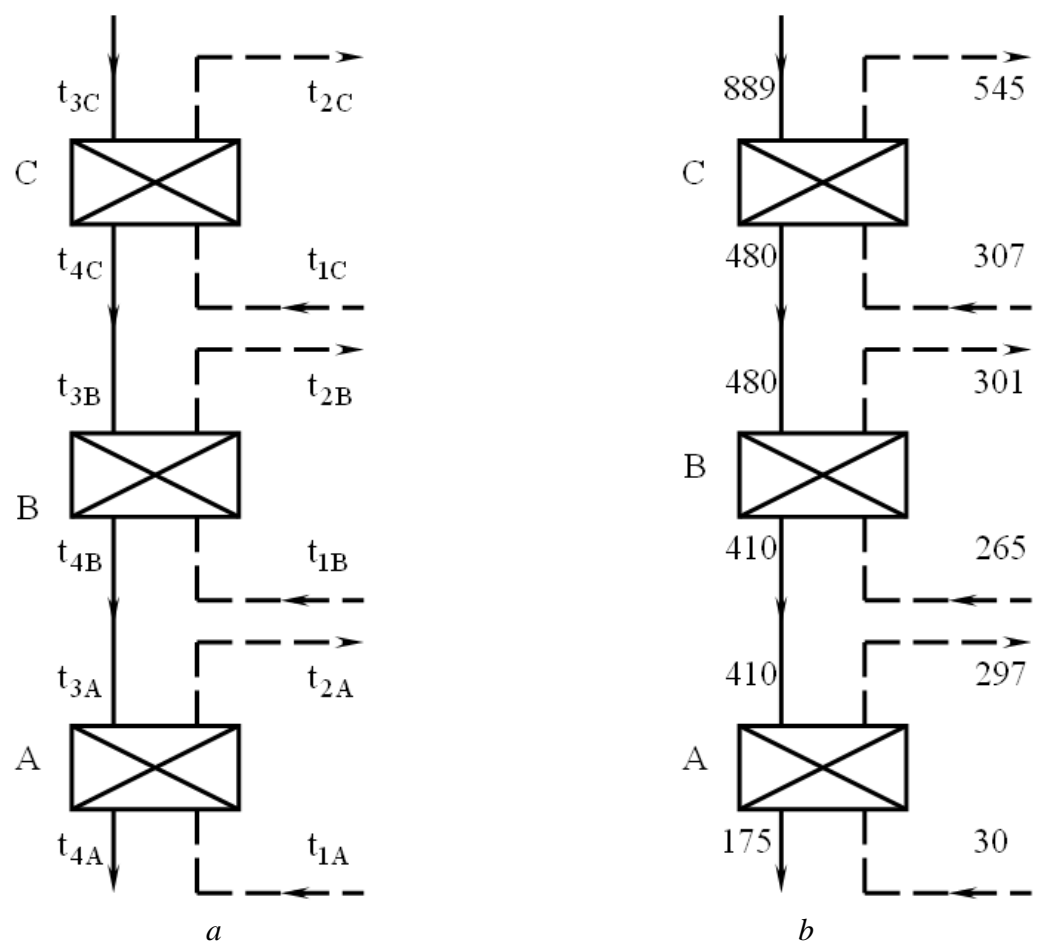

Fig.2. The basic structural scheme of the convective heat transfer system of the TPP-210A steam boiler: $\mathrm{A}$ - air heater; $\mathrm{B}$ - water economiser; $\mathrm{C}$ - intermediate superheater (digits mark the value of the temperature $\left({ }^{\circ} \mathrm{C}\right)$ of the heat carriers in the nominal mode)

Let us develop the mathematical model of the basic structural scheme of the heat transfer system and perform calculations of the mode coefficients for the initial state.

The equations of the HTS elements will appear as

$$
t_{2 N}=\left(1-W_{2 N}\right) \cdot t_{1 N}+W_{2 N} \cdot t_{3 N} ; \quad t_{4 N}=\left(1-W_{4 N}\right) \cdot t_{1 N}+W_{4 N} \cdot t_{3 N} ; \quad N \in\{A, B, C\} .
$$

The equation of the HTS elements couplings will be:

$$
t_{3 B}=t_{4 C} ; t_{3 A}=t_{4 B} .
$$

The generalized parameters of the HTS elements will be defined as

$$
\begin{aligned}
& W_{2 N}=\frac{t_{2 N}-t_{1 N}}{t_{3 N}-t_{1 N}}: W_{2 C}=\frac{545-307}{889-307}=0.4089 ; \quad W_{2 B}=\frac{301-265}{480-265}=0.1674 ; \quad W_{2 A}=\frac{297-30}{410-30}=0.7026 . \\
& W_{4 N}=\frac{t_{4 N}-t_{1 N}}{t_{3 N}-t_{1 N}}: W_{4 C}=\frac{480-307}{889-307}=0.2973 ; \quad W_{4 B}=\frac{410-265}{480-265}=0.6744 ; \quad W_{4 A}=\frac{175-30}{410-30}=0.3816 .
\end{aligned}
$$

The mathematical model of the base HTS structural scheme will have the following form

$$
\begin{gathered}
t_{i N}=K_{i N 1 A} \cdot t_{1 A}+K_{i N 1 B} \cdot t_{1 B}+K_{i N 1 C} \cdot t_{1 C}+K_{i N 3 C} \cdot t_{3 C}, \\
\Delta t_{i N}=K_{i N 1 A} \cdot \Delta t_{1 A}+K_{i N 1 B} \cdot \Delta t_{1 B}+K_{i N 1 C} \cdot \Delta t_{1 C}+K_{i N 3 C} \cdot \Delta t_{3 C},
\end{gathered}
$$

where $i$ is the index of the output flow ("2", " 4 "); $N$ is the name of the subsystem $(A, B, C) ; 1 A$ is the index of the input flow "1" of the subsystem $A, 1 B, 1 C, 3 C$ are indices of the input flows " 1 " and " 3 " of the subsystems $B$ and $C$; $K_{i N}$ is the coefficient comprising only the HTS object parameters;

For a particular $t_{i N}$, there exists the equation $\sum K_{i N}=1.0$. 
The formation of the HTS model will appear as

$$
\begin{aligned}
& t_{2 C}=\left(1-W_{2 C}\right) \cdot t_{1 C}+W_{2 C} \cdot t_{3 C} ; \\
& t_{4 C}=\left(1-W_{4 C}\right) \cdot t_{1 C}+W_{4 C} \cdot t_{3 C}=t_{3 B} ; \\
& t_{2 B}=\left(1-W_{2 B}\right) \cdot t_{1 B}+W_{2 B} \cdot t_{3 B}=\left(1-W_{2 B}\right) \cdot t_{1 B}+W_{2 B} \cdot\left(1-W_{4 C}\right) \cdot t_{1 C}+W_{2 B} \cdot W_{4 C} \cdot t_{3 C} ; \\
& t_{4 B}=\left(1-W_{4 B}\right) \cdot t_{1 B}+W_{4 B} \cdot t_{3 B}=\left(1-W_{4 B}\right) \cdot t_{1 B}+W_{4 B} \cdot\left(1-W_{4 C}\right) \cdot t_{1 C}+W_{4 B} \cdot W_{4 C} \cdot t_{3 C}=t_{3 A} ; \\
& t_{2 A}=\left(1-W_{2 A}\right) \cdot t_{1 A}+W_{2 A} \cdot t_{3 A}=\left(1-W_{2 A}\right) \cdot t_{1 A}+W_{2 A} \cdot\left(1-W_{4 B}\right) \cdot t_{1 B}+W_{2 A} \cdot W_{4 B} \cdot\left(1-W_{4 C}\right) \cdot t_{1 C}+W_{2 A} \cdot W_{4 B} \cdot W_{4 C} \cdot t_{3 C} ; \\
& t_{4 A}=\left(1-W_{4 A}\right) \cdot t_{1 A}+W_{4 A} \cdot t_{3 A}=\left(1-W_{4 A}\right) \cdot t_{1 A}+W_{4 A} \cdot\left(1-W_{4 B}\right) \cdot t_{1 B}+W_{4 A} \cdot W_{4 B} \cdot\left(1-W_{4 C}\right) \cdot t_{1 C}+W_{4 A} \cdot W_{4 B} \cdot W_{4 C} \cdot t_{3 C} \cdot
\end{aligned}
$$

The equations for calculating the mode coefficients are presented in Table 1, and the values of these coefficients depend only on the object parameters.

Table 1. The equations of the mode (object) coefficients.

\begin{tabular}{|c||c|c|c|c|}
\hline$t_{i N}$ & $K_{i N 1 A}$ & $K_{i N 1 B}$ & $K_{i N 1 C}$ & $K_{i N 3 C}$ \\
\hline \hline$t_{2 C}$ & 0 & 0 & $1-W_{2 C}$ & $W_{2 C}$ \\
\hline$t_{4 C}$ & 0 & 0 & $1-W_{4 C}$ & $W_{4 C}$ \\
\hline$t_{2 B}$ & 0 & $1-W_{2 B}$ & $W_{2 B} \cdot\left(1-W_{4 C}\right)$ & $W_{2 B} \cdot W_{4 C}$ \\
\hline$t_{4 B}$ & 0 & $1-W_{4 B}$ & $W_{4 B} \cdot\left(1-W_{4 C}\right)$ & $W_{4 B} \cdot W_{4 C}$ \\
\hline$t_{2 A}$ & $1-W_{2 A}$ & $W_{2 A} \cdot\left(1-W_{4 B}\right)$ & $W_{2 A} \cdot W_{4 B} \cdot\left(1-W_{4 C}\right)$ & $W_{2 A} \cdot W_{4 B} \cdot W_{4 C}$ \\
\hline$t_{4 A}$ & $1-W_{4 A}$ & $W_{4 A} \cdot\left(1-W_{4 B}\right)$ & $W_{4 A} \cdot W_{4 B} \cdot\left(1-W_{4 C}\right)$ & $W_{4 A} \cdot W_{4 B} \cdot W_{4 C}$ \\
\hline
\end{tabular}

The generalized view of the HTS model will be

$$
\begin{aligned}
& t_{2 N}=K_{2 N 1 A} \cdot t_{1 A}+K_{2 N 1 B} \cdot t_{1 B}+K_{2 N 1 C} \cdot t_{1 C}+K_{2 N 3 C} \cdot t_{3 C} ; \\
& t_{4 N}=K_{4 N 1 A} \cdot t_{1 A}+K_{4 N 1 B} \cdot t_{1 B}+K_{4 N 1 C} \cdot t_{1 C}+K_{4 N 3 C} \cdot t_{3 C} .
\end{aligned}
$$

When checking the results, it should be taken into account that

$$
K_{i N 1 A}+K_{i N 1 B}+K_{i N 1 C}+K_{i N 3 C}=1.0
$$

The numeric values of the mode coefficients for a set initial state of the steam boiler are presented in Table 2 .

Table 2. The values of $K_{i N}$ for the initial values of the object parameters.

\begin{tabular}{|c||c|c|c|c|}
\hline$t_{i N}$ & $K_{i N 1 A}$ & $K_{i N 1 B}$ & $K_{i N 1 C}$ & $K_{i N 3 C}$ \\
\hline \hline$t_{2 C}$ & 0 & 0 & 0.591 & 0,409 \\
\hline$t_{4 C}$ & 0 & 0 & 0.703 & 0.297 \\
\hline$t_{2 B}$ & 0 & 0.833 & 0.118 & 0.049 \\
\hline$t_{4 B}$ & 0 & 0.326 & 0.474 & 0.200 \\
\hline$t_{2 A}$ & 0.297 & 0.229 & 0.333 & 0.141 \\
\hline$t_{4 A}$ & 0.618 & 0.124 & 0.181 & 0.077 \\
\hline
\end{tabular}

The correlations between the temperatures will be

$t_{2 C}=0 \cdot t_{1 A}+0 \cdot t_{1 B}+0.591 \cdot t_{1 C}+0.409 \cdot t_{3 C} ;$ 


$$
\begin{aligned}
& t_{4 C}=0 \cdot t_{1 A}+0 \cdot t_{1 B}+0.703 \cdot t_{1 C}+0.297 \cdot t_{3 C} ; \\
& t_{2 B}=0 \cdot t_{1 A}+0.833 \cdot t_{1 B}+0.118 \cdot t_{1 C}+0.049 \cdot t_{3 C} ; \\
& t_{4 B}=0 \cdot t_{1 A}+0.326 \cdot t_{1 B}+0.474 \cdot t_{1 C}+0.200 \cdot t_{3 C} ; \\
& t_{2 A}=0.297 \cdot t_{1 A}+0.229 \cdot t_{1 B}+0.333 \cdot t_{1 C}+0.141 \cdot t_{3 C} ; \\
& t_{4 A}=0.618 \cdot t_{1 A}+0.124 \cdot t_{1 B}+0.181 \cdot t_{1 C}+0.077 \cdot t_{3 C} ; \\
& 0.618+0.124+0.181+0.077=1 .
\end{aligned}
$$

The correlations between the changes of the temperatures will be

$$
\begin{aligned}
& \Delta t_{2 C}=0 \cdot \Delta t_{1 A}+0 \cdot \Delta t_{1 B}+0.591 \cdot \Delta t_{1 C}+0.409 \cdot \Delta t_{3 C} ; \\
& \ldots \ldots \\
& \Delta t_{4 A}=0.618 \cdot \Delta t_{1 A}+0.124 \cdot \Delta t_{1 B}+0.181 \cdot \Delta t_{1 C}+0.077 \cdot \Delta t_{3 C} .
\end{aligned}
$$

As the temperature of the cold air rises by $10{ }^{\circ} \mathrm{C}\left(\Delta t_{1 \mathrm{~A}}=10{ }^{\circ} \mathrm{C}\right)$, the temperature of the offgases rises by $6.2{ }^{\circ} \mathrm{C}$ $\left(\Delta t_{4 \mathrm{~A}}=6.2^{\circ} \mathrm{C}\right)$.

If the increase in the flue gases temperature at the HTS inlet is $10{ }^{\circ} \mathrm{C}$, the temperature of the offgases will increase by $0.8{ }^{\circ} \mathrm{C}$.

If the object parameters in the subsystem $N$ changes, this correspondingly has an effect on the values of $W_{2 N}$ and $W_{4 N}$, which, in turn, influences the mode coefficients.

The expressions for the offgases will be

$$
\begin{aligned}
& K_{4 A 1 A_{X}}=1-W_{4 A}=K_{4 A 1 A} ; \\
& K_{4 A 1 B_{X}}=W_{4 A} \cdot\left(1-W_{4 B}\right)=K_{4 A 1 B} ; \\
& K_{4 A 1 C_{X}}=W_{4 A} \cdot W_{4 B} \cdot\left(1-W_{4 C_{X}}\right) ; \\
& K_{4 A 3 C_{X}}=W_{4 A} \cdot W_{4 B} \cdot W_{4 C_{X}},
\end{aligned}
$$

where subscript $X$ is used to signify the parameters in a changed mode.

As we can see, in this particular case the values of only two mode coefficients change. Then the temperature change can be defined by the equation

$$
\Delta t_{4 A}=t_{4 A_{X}}-t_{4 A}=W_{4 A} \cdot W_{4 B} \cdot\left(t_{3 C}-t_{1 C}\right) \cdot\left(W_{4 C_{X}}-W_{4 C}\right) .
$$

For a set mode of the steam boiler:

$$
\Delta t_{4 A}=0.3816 \cdot 0.6744 \cdot(889-307) \cdot \Delta W_{4 C}=149.5 \cdot \Delta W_{4 C} \cdot
$$

The assessment of $W_{4 C}$ change is an autonomous problem of calculations in system $C$.

\section{Conclusion}

The feasibility and efficiency of mode calculations of the heating surfaces of the operating steam boilers based on the temperatures of the heat carriers known only in one of the operation modes have been demonstrated; the heat carrier flow, area and condition of the heating surfaces can be unknown.

For the TPP-210A steam boilers of the Trypillia Thermal Power Station, a structural scheme and mathematical model of the convective heat transfer system to be applied for mode calculations was developed. 
It was established that for a $10{ }^{\circ} \mathrm{C}$ increase in the temperature of cold air, the temperature of the TPP-210A boiler offgases temperature rises by $6.2^{\circ} \mathrm{C}$. If the temperature of flue gases at the inlet to HTS increases by $10{ }^{\circ} \mathrm{C}$, the offgases temperature increases by $0.8^{\circ} \mathrm{C}$.

\title{
References
}

[1] Nusselt W. A new formula for heat transfer in cross flow. Technical Mechanics and Thermodynamics, 1930, V. 1, No. 12, pp.417-422. (in German)

[2] Smith D. M. Mean temperature difference in cross flow. Engineering, 1934, Vol. 138, No. 3590, pp. $479-481$.

[3] Chaban O. J. Analysis of non-nominal modes of convective stages of boilers. ORGRES tuning and experimental works, issue XXXIX. M.: Energy, 1970, pp.133-145. (in Russian)

[4] Chaban O. J., Kruk M. T. Adjustment design of modes of heat-and-power equipment of power-generating units. Power Engineering and Electrification, series Service and Maintenance of Power Stations, Vol. 12. - M.: Informenergo, 1979, pp. 5-41. (in Russian)

[5] Chaban O. I., Ostapyuk R. V., Stashkiv M. G. Relationship of temperatures in complex heat exchange systems. Mashinostroyeniye. - 1975. - Vol. 4. - pp. 28-30. (in Russian)

[6] Chaban, O. Y., Galyanchuk I. R. Models and designing of elementary convective heat exchangers. Proceedings of Lviv Polytechnic National University. "Thermal Power Engineering. Environment Engineering. Automation”, 1999, Vol. 365, pp. 32-40. (in Ukrainian)

[7] Galyanchuk I. R., Kuznetsova M. J. Mathematical models of heat-transfer system for double- and triple-pass heat exchangers. EasternEuropean Journal of Enterprise Technologies. Kharkiv, 2013, Vol. 2, Issue 8 (62). - pp. 29 - 32. (in Ukrainian)

[8] Galyanchuk I. R., Kuznetsova M. Y. Mathematical modelling and investigation of properties of air heater for boiler. Proceedings of Lviv Polytechnic National University. "Thermal Power Engineering. Environment Engineering. Automation”, 2014, Vol. 795, pp. 40-50. (in Ukrainian)

[9] Mysak J., Galyanchuk I., Kuznetsova M. Development of mathematical models and the calculations of elements of convective heat transfer systems. Eastern-European Journal of Enterprise Technologies. 2016, Vol. 82, No. 4/8, p. 33-41. https://doi.org/10.15587/17294061.2016.74826

\section{Математичне моделювання теплопередавальної системи конвективних поверхонь нагріву парового котла ТПП-210А}

\author{
Ігор Галянчук, Тарас Кравець \\ Наиіональний університет «Львівська політехніка», вул. С. Бандери 12, Львів, 79013, Украӥна
}

\section{Анотація}

Розроблено математичну модель та відповідну структурну схему конвективних поверхонь нагріву парового котла ТПП-210А у вигляді системи взаємозв'язаних теплообмінників. Поєднані між собою конвективні поверхні нагріву розглядаються як конвективна теплопередавальна система парового котла. Отримані результати моделювання конвективної теплопередавальної системи дозволяють виконувати режимні розрахунки залежності температурного і теплового режиму поверхонь нагріву від зміни вхідних температур теплоносіїв, відносних змін витрати теплоносіїв, а також площі поверхонь нагріву. Дану математичну модель доцільно застосовувати для виявлення можливих удосконалень конвективної теплопередавальної системи, а також для визначення наслідків внесених змін у теплопередавальну систему на основі відомих тільки вхідних та вихідних температур теплоносіїв у початковому режимі.

Ключові слова: математична модель; теплопередавальна система; конвективні поверхні нагріву; схема; параметри; температура; теплоносій; теплообмінник. 